\title{
Hesx1 homeodomain protein represses transcription as a monomer and antagonises transactivation of specific sites as a homodimer
}

\author{
J Quirk and P Brown \\ MRC Human Reproductive Sciences Unit, 37 Chalmers Street, Edinburgh EH3 9ET, UK \\ (Requests for offprints should be addressed to P Brown; Email: p.brown@hrsu.mrc.ac.uk)
}

\begin{abstract}
The homeobox repressor Hesx1, expressed throughout Rathke's pouch and required for normal pituitary development, has been implicated in anterior pituitary pathogenesis in man. Prolonged expression of Hes $x 1$ delays the appearance of anterior pituitary terminal differentiation markers in mice, particularly the gonadotroph hormones. We tested if Hesx1 could modulate gonadotrophin gene expression directly, and found that Hesx1 repressed both common alpha subunit ( $\alpha \mathrm{GSU}$ ) and luteinising hormone $\beta$-subunit (LH $\beta$ ) gene promoters. Repression mapped to the Pitx1 homeodomain protein transactivation site in the proximal $\alpha$ GSU promoter, but did not map to the equivalent site on LH $\beta$. Hesx 1 repression of the $\alpha \mathrm{GSU}$ Pitx1 site was overridden by co-transfection of Pitx 1 . In contrast, Hesx 1 antagonised Pitx 1 transactivation of LH $\beta$ in a dose-dependent manner. This was due to monomeric binding of Hesx1 on $\alpha \mathrm{GSU}$ and homodimerisation on LH $\beta$. The homodimerisation site comprises the Pitx1 DNA binding site and a proximal binding site, and mutation of either inhibited homodimer formation. Conversion of the LH $\beta$ Pitx1 DNA binding site to an $\alpha$ GSU-type did not promote homodimer formation, arguing that Hes $x 1$ has pronounced site selectivity. Furthermore, mutation of the proximal half of the homodimerisation site blocked Hesx 1 antagonisation of Pitx 1 transactivation. We conclude that Hesx 1 monomers repress gene expression, and homodimers block specific transactivation sites.
\end{abstract}

Journal of Molecular Endocrinology (2002) 28, 193-205

\section{Introduction}

Homeodomain genes are crucial for controlling and specifying development of the pituitary gland (Watkins-Chow \& Camper 1998, Dasen \& Rosenfeld 1999). Correct spatial expression of homeodomain proteins, defined by morphogen signalling gradients, is necessary for stratifying the anterior pituitary (Treier et al. 1998) into the constituent cell-types: gonadotrophs, thyrotrophs, somatotrophs, lactotrophs and corticotrophs. A number of homeodomain genes have been implicated in commitment, cellular expansion and expression of terminal markers in these constituent cell-types (Bach et al. 1995, Gage et al. 1996, Hermesz et al. 1996, Lamonerie et al. 1996, Sheng et al. 1996, Sornson et al. 1996, Acampora et al. 1998, Dattani et al. 1998, Tremblay et al. 1998, Gage et al.
1999, Szeto et al. 1999, Cushman et al. 2001, Thomas et al. 2001).

It is becoming increasingly evident that the combinatorial expression pattern of homeodomain factors is critical for regulation of pituitary gene expression. For instance, prophet of Pit-1 (Prop-1), which activates Pit-1 gene expression in thyrotrophs, somatotrophs and lactotrophs (Sornson et al. 1996), is known to extinguish gene expression of another paired-like homeodomain factor Hesx 1 (Gage et al. 1996, Sornson et al. 1996). Furthermore, paired-like pituitary factor-1 (Pitxl) is required for expression of all the differentiated cell markers in the anterior pituitary (Lamonerie et al. 1996, Tremblay et al. 1998, Szeto et al. 1999), but not for overall pituitary development, although the delayed expression of gonadotroph terminal differentiation markers clearly indicates a role for Pitxl in this 
cell-type (Szeto et al. 1999). The genetic targets of Pitxl are well defined (Tremblay et al. 1998, Quirk et al. 2001), with Pitx1 modulating expression of pituitary terminal differentiation markers by interacting with non-homeodomain factors (Tremblay et al. 1999, Poulin et al. 2000, Lamolet et al. 2001).

The gene expression profiles of Hesx 1 and Pitx 1 overlap during pituitary development (Hermesz et al. 1996, Lanctot et al. 1999), but the gene targets for Hesx 1 have not been identified, and potential interaction between these factors has not been investigated. Hesx 1 is a homeodomain repressor protein in vivo (Ermakova et al. 1999) and both the N-terminal and C-terminal domains, when expressed as a GAL4 DNA-binding domain fusion protein, can recruit nuclear corepressor (N-CoR) and repress (Xu et al. 1998). It is known, however, that Hesx 1 gene expression is crucial for normal pituitary development in man and mouse (Dattani et al. 1998, Thomas et al. 2001), and continued expression prevents pituitary expansion prior to terminal differentiation (Gage et al. 1996, Wu et al. 1998). Furthermore, haploinsufficiency of Hesx 1, associated with combined pituitary hormone deficiency (CPHD) in man, is as damaging as loss of function (Dattani et al. 1998, Thomas et al. 2001). Expression of Hesx 1 is initially dispersed throughout the presumptive pituitary; however this gradually regresses in a ventral to dorsal manner (Hermesz et al. 1996). The presumptive gonadotrophs form along the ventral axis (Treier et al. 1998), and continuous expression of Hesx 1 perturbs gonadotroph cell commitment (Gage et al. 1996, Wu et al. 1998). Thus, prolonged expression, or loss of expression, or changes in levels of expression of Hesx 1 homeodomain repressor are detrimental to anterior pituitary and gonadotroph function, as assessed by expression of the terminal differentiation markers, luteinising hormone $\beta$-subunit (LH $\beta$ ) and follicle-stimulating hormone $\beta$-subunit $(\mathrm{FSH} \beta)$. Although, on cognate palindromic binding sites, Hesx 1 can either heterodimerise with Prop-1 or homodimerise (Sornson et al. 1996, Dattani et al. 1998), the targets of this molecular interaction and the molecular mode of action of Hesxl are unknown.

Gonadotrophin gene transcription is controlled by a complex combination of transcription factors (Brown \& McNeilly 1999) including Pitx1 (Tremblay et al. 1998, Quirk et al. 2001). Since the expression profiles of Hesx 1 and Pitx1 overlap
(Hermesz et al. 1996, Lanctot et al. 1999), and persistent expression of Hesx 1 perturbs expression of the gonadotrophin genes in mice (Gage et al. 1996) and also presumably in man (Wu et al. 1998), we reasoned that Hesxl may modulate Pitx 1 transactivation of gene expression, and that Hesx 1 may repress gonadotrophin gene expression. Thus, we have used a model system of transient transfection assay of a Hesxl protein expression construct and the common $\alpha$-subunit $(\alpha \mathrm{GSU})$ and LH $\beta$ gonadotrophin gene promoters. Hesxl does indeed repress expression of both the $\alpha \mathrm{GSU}$ and LH $\beta$ gene promoters. Furthermore, Hesxl homodimerised on a novel paired-like homeodomain binding site in the LH $\beta$ gene promoter, and antagonised Pitxl transactivation. In contrast, Hesx 1 bound the $\alpha$ GSU Pitx 1 transactivation site as a monomer and did not antagonise Pitxl activated gene expression, when co-transfected. This suggests that the molecular mode of action of Hesxl on the gonadotrophin gene promoters is to act as a short-range monomeric repressor and antagonise transactivation as a homodimer.

\section{Materials and methods}

\section{Cell culture and transfection assays}

HeLa cells were grown in DMEM supplemented with 10\% FCS and 1\% penicillin/streptomycin. Cells were seeded at 50000 cells per well in 12-well tissue culture dishes $24 \mathrm{~h}$ prior to transfection. On the morning of transfection, cell media were replaced and cells were transfected using Fugene 6 transfection reagent (Roche Diagnostics), in a ratio of 3 volumes of Fugene to 1 weight of DNA, according to the manufacturer's protocols. For the promoter resection experiments, $25 \mathrm{ng}$ of a control $\beta$-galactosidase construct, $1.5 \mu \mathrm{g}$ reporter construct, $250 \mathrm{ng}$ of each effector plasmid and pBluescript II (Roche Diagnostics) carrier DNA, to a total of $2 \mu \mathrm{g}$, were transfected per well. For the minimal promoter experiments, $25 \mathrm{ng}$ of a control $\beta$ galactosidase construct, $0.5 \mu \mathrm{g}$ reporter construct, between 31-125 ng of each effector plasmid and pBluescript II carrier DNA to a total of $2 \mu \mathrm{g}$ were transfected per well. Cells were harvested $48 \mathrm{~h}$ post-transfection and luciferase/ $\beta$-galactosidase activity was determined using a chemiluminescent assay (Dual Light, Perkin Elmer) in an LB96 V luminometer (Bertold Technologies, Bad Wildbad, 
Germany). All transfections were carried out in triplicate, repeated three times and corrected for $\beta$-galactosidase activity. Basal promoter expression levels were normalised to 1 and expression levels were calculated relative to this. All results are expressed as the mean \pm s.E.M.

Murine L-cells were grown in DMEM supplemented with 10\% FCS and 1\% penicillin/ streptomycin. Cells were seeded at 1500000 cells $/ 75 \mathrm{~cm}^{3}$ tissue culture flask $24 \mathrm{~h}$ prior to transfection. On the morning of transfection, cell media were exchanged for Optimem (Invitrogen). Subsequently, $30 \mu \mathrm{g}$ effector plasmid were transfected using Gene Porter (Gene Therapies Inc. San Diego, CA, USA) and, after $4 \mathrm{~h}$, transfection media were exchanged for DMEM/ $10 \%$ FCS. Cells were harvested for nuclear extract preparation after $48 \mathrm{~h}$.

\section{Electrophoretic mobility shift assay (EMSA) analysis}

L-cell nuclear protein extracts were harvested using a modified protocol (Schreiber et al. 1989). Top and bottom strand oligonucleotides were synthesised (Sigma-Genosys Ltd) and annealed before endlabelling with $3000 \mathrm{Ci} / \mathrm{mmol} \gamma$-ATP using T4 polynucleotide kinase (Roche Diagnostics). A $5 \mu \mathrm{g}$ aliquot of nuclear extract was pre-incubated on ice for $10 \mathrm{~min}$ in Pitxl binding buffer $(25 \mathrm{mM}$ HEPES, $\mathrm{pH} 7 \cdot 6,84 \mathrm{mM} \mathrm{KCl}, 5 \mathrm{mM}$ dithiothreitol, $10 \%$ glycerol) with $5 \mu \mathrm{g}$ polydI-dC (Sigma Ltd) and Complete protease inhibitors (Roche Diagnostics) before adding 30000 c.p.m. oligonucleotide and incubating for $30 \mathrm{~min}$ on ice. Complexes were resolved on $6 \%$ PAGE gels in $0.5 \times$ TBE $(45 \mathrm{mM}$ Tris-borate, $1 \mathrm{mM}$ EDTA, pH 8.3) at $10 \mathrm{v} / \mathrm{cm}$.

\section{Plasmid DNA constructs}

Resections of the ovine $\mathrm{LH} \beta$ and murine $\alpha \mathrm{GSU}$ gene promoters, generated using Exonuclease III (Amersham Pharmacia Biotech), were fused upstream of a luciferase reporter in the vector $\mathrm{pA} 3$ LUC. Hesx 1 and Pitxl expression constructs were generated in the eukaryotic expression vector pCDNA 3 (Invitrogen). Oligonucleotides containing 3 copies of a fragment spanning the homeodomain binding site from $\alpha \mathrm{GSU}, \mathrm{LH} \beta$, the mutant M3 or a synthetic consensus sequence PIII respectively, were synthesised (Sigma Genosys) with overhanging KpnI and NheI sites and ligated upstream of a minimal thymidine kinase promoter in the vector pTAL-Luc (BD Biosciences, UK).

\section{Bioinformatics and statistics}

All DNA sequence comparisons were carried out using Wisconsin Package version 10·2, Genetics Computer Group (GCG), Madison, WI, USA, housed on the Medical Research Council's Human Genome Mapping Project server (MRC HGMP, Hinxton, UK). Statistical significance was established as $P<0.05$ using ANOVA one-way analysis of variance on Statview 4.02 (SAS, Cary, NC, USA).

\section{Results}

\section{Hesx 1 represses transcription of the $\alpha \mathrm{GSU}$ and LH $\beta$ gene promoters}

A -480 bp fragment of $\alpha$ GSU and -320 bp of LH $\beta$ gene promoter were fused upstream of a luciferase reporter and transfected into HeLa cells to determine basal reporter gene expression levels, which were expressed as 1 (Fig. 1a). A Hesx 1 expression vector was co-transfected with these promoters and the change in luciferase gene expression calculated relative to basal levels (Fig. 1a). Since Hesxl repressed expression of both $\alpha \mathrm{GSU}$ and LH $\beta$ gene promoters, a series of resections were used to map the site of repression (Fig. 1b and c). The site of $\alpha \mathrm{GSU}$ promoter repression was mapped between $\alpha \mathrm{GSU}$ resections -120 and -109 bp (Fig. 1b), while co-transfection of Hesxl did not affect basal promoter activity of either -136 or -80 bp LH $\beta$ gene promoters. This paradoxically suggests that the homeodomain DNA binding site contained within the -120 bp aGSU resection could be a DNA target for Hesx 1 repression, but the site encoded within the $-136 \mathrm{bp}$ LH $\beta$ promoter was not. These two homeodomain DNA binding sites are targets for the paired-like homeodomain transcriptional activator Pitx1 (Tremblay et al. 1998). The DNA sequence of these sites differ, the aGSU Pitxl DNA binding site 5'-CTTA-3' varies from the consensus homeodomain binding site $5^{\prime}$-ATTA- $3^{\prime}$ present in LH $\beta$. Therefore, this difference in repression of gene expression by Hesxl of the two promoters, via these two homeodomain DNA binding sites, was further investigated. 

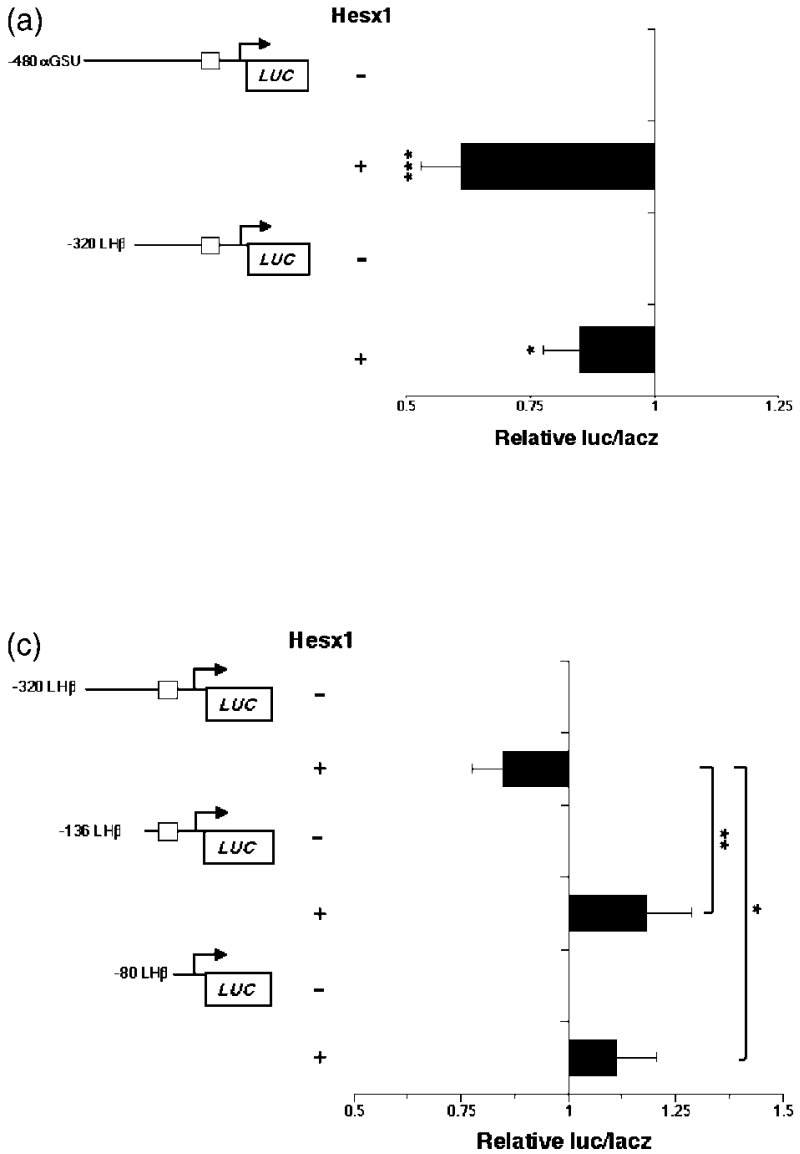

\section{Hesx1 can modulate Pitx1 transactivation of gene expression}

A Pitxl expression construct was transfected with $-480,-120$ and $-109 \mathrm{bp}$ resections of the $\alpha \mathrm{GSU}$ gene promoter into HeLa cells. As expected, Pitxl transactivated the -480 and $-120 \mathrm{bp}$ constructs (Fig. 2a). However, when Hesx 1 was co-transfected with Pitxl, Hesxl attenuated Pitxl transactivation of the $-480 \mathrm{bp} \alpha \mathrm{GSU}$ construct, but did not repress, and had a variable effect on expression of the $-120 \alpha$ GSU resection (Fig. 2a). This experiment was repeated for the LH $\beta$ gene promoter (Fig. 2b). In this instance, Pitx 1 transactivated both the -320 and $-136 \mathrm{bp}$ gene promoters, again as expected, but this was modulated by cotransfection of Hesxl. Although Hesxl did not repress the -136 bp LH $\beta$ gene promoter per se (Fig. 1c), when Hesxl was co-transfected with Pitxl, gene expression was reduced (although not significantly, a value of $P<0.07$ was obtained for -136 bp LH $\beta+$ Pitx 1 vs -136 bp LH $\beta+$ Pitx $1+$

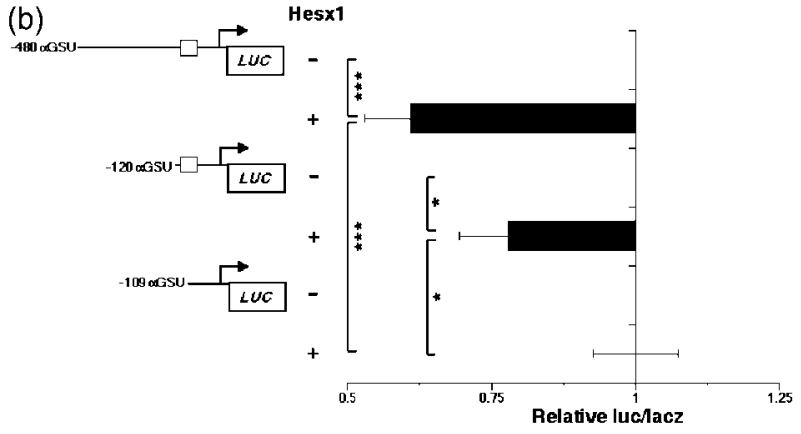

Figure 1 Hesx 1 homeodomain represses $\alpha$ GSU and LH $\beta$ gene promoter activity. Hesx1 was co-transfected with either $\alpha \mathrm{GSU}$ or $\mathrm{LH} \beta$ promoters into HeLa cells and luciferase activity was measured. (a) -480 bp $\alpha G S U$ and -320 bp LH $\beta$ gene promoter activity was repressed by Hesx1. ${ }^{* \star *} P<0 \cdot 001,-480$ bp $\alpha$ GSU vs -480 bp $\alpha \mathrm{GSU}+$ Hesx1; ${ }^{\star} P<0.05,-320$ bp LH $\beta$ vs -320 bp LH $\beta+$ Hesx1. (b) Hesx1 repression mapped to between -120 and $-109 \mathrm{bp}$ of the $\alpha \mathrm{GSU}$ promoter. ${ }^{* * *} P<0.001,-480 \mathrm{bp}$ $\alpha \mathrm{GSU}+$ Hesx1 vs -480 bp $\alpha \mathrm{GSU}$ and -109 bp $\alpha \mathrm{GSU}+$ Hesx 1; * $P<0.05,-120$ bp $\alpha$ GSU + Hesx1 vs -120 bp $\alpha G S U$ and -109 bp $\alpha \mathrm{GSU}+$ Hesx1. (c) Only the $-320 \mathrm{bp}$ $\mathrm{LH} \beta$ promoter was repressed by Hesx1, and not the -136 or $-80 \mathrm{bp} \mathrm{LH} \beta$ promoter resections. ${ }^{* *} P<0 \cdot 01,-320 \mathrm{bp}$ $\mathrm{LH} \beta+$ Hesx1 vs -136 bp LH $\beta+$ Hesx $1 ;{ }^{*} P<0 \cdot 05$, -320 bp LH $\beta+$ Hesx1 vs -80 bp LH $\beta+$ Hesx1. Basal promoter expression in the absence of Hesx1 (-) was expressed as 1 , and determined by dividing luciferase activity by $\beta$-galactosidase activity. Co-transfection of Hesx 1 is denoted by + . The known Pitx1 homeodomain binding sites are depicted by open boxes.

Hesx 1) but again, as for aGSU, gene expression was not repressed below basal. The insensitivity of the -80 bp LH $\beta$ promoter to either Pitxl or Hesx 1 suggests that the effect is mediated via the Pitxl DNA binding site contained within the $-136 \mathrm{bp}$ LH $\beta$ promoter.

\section{The novel LH $\beta$ paired homeodomain binding site is conserved across species}

It was possible that the differences between Hesxl repression of the two promoters, $-120 \mathrm{bp} \alpha \mathrm{GSU}$ and $-136 \mathrm{bp} \mathrm{LH} \beta$, were due to differences in the cognate DNA binding sites on the $\alpha \mathrm{GSU}$ and LH $\beta$ promoters. Examination of the -136 bp LH $\beta$ gene promoter fragment identified a potential homeodomain DNA binding site $8 \mathrm{bp}$ proximal to the Pitxl DNA binding site 5'agATTAgtgtccagGTTAc- $3^{\prime}$; both sites are shown in bold, with the putative site underlined. The DNA sequence corresponding to this novel paired 
(a)

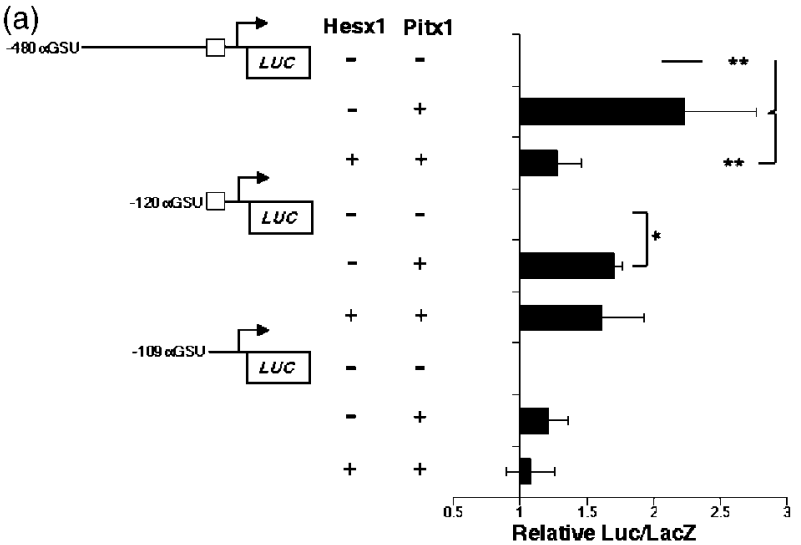

(b)

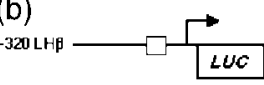

Hesx1 Pitx1

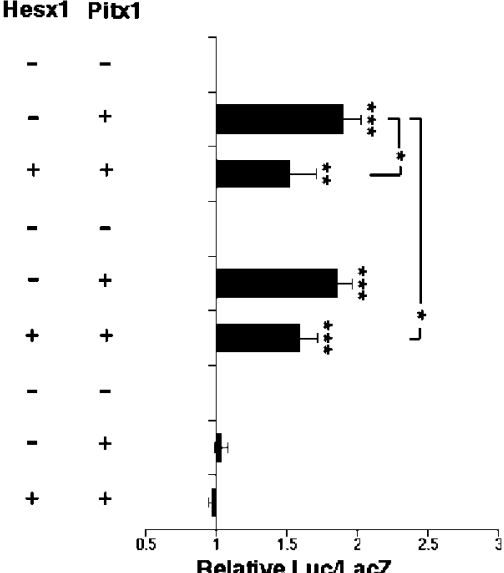

Figure 2 Modulation of Pitx 1 transactivation of the $\alpha$ GSU and LH $\beta$ promoters by Hesx 1 . Pitx 1 or both Pitx 1 and Hesx 1 were co-transfected with $\alpha$ GSU or LH $\beta$ promoters. (a) Pitx 1 transactivated the $-480 \mathrm{bp}$ and $-120 \mathrm{bp}$, but not the -109 bp $\alpha \mathrm{GSU}$ promoters. Co-transfection of Pitx1 and Hesx1 down-regulated Pitx1 transactivation of the -480 bp $\alpha$ GSU promoter. ${ }^{* *} P<0 \cdot 01,-480$ bp $\alpha \mathrm{GSU}+$ Pitx1 vs -480 bp $\alpha \mathrm{GSU}$ and -480 bp $\alpha \mathrm{GSU}+$ Pitx1 + Hesx1. ${ }^{*} P<0.05,-120$ bp $\alpha$ GSU + Pitx 1 vs -120 bp $\alpha$ GSU. (b) The -320 and -136 bp LH $\beta$ promoters were transactivated by Pitx1. This transactivation was diminished by co-transfection of Pitx 1 and Hesx 1 . The -80 bp LH $\beta$ promoter was insensitive to both Pitx1 and Hesx1. ${ }^{* *} P<0.001,-320$ bp LH $\beta$ vs -320 bp LH $\beta+$ Pitx $1 ;{ }^{* * *} P<0.001,-136$ bp LH $\beta$ vs -136 bp LH $\beta+$ Pitx1 and -136 bp LH $\beta+$ Pitx1 + Hesx1; ${ }^{* *} P<0 \cdot 01,-320$ bp LH $\beta+$ Hesx1 vs -320 bp LH $\beta ;{ }^{*} P<0 \cdot 05$, -320 bp LH $\beta$ + Pitx1 vs -320 bp LH $\beta+$ Pitx $1+$ Hesx1 and -136 bp LH $\beta+$ Pitx1 + Hesx1. Results are expressed relative to basal promoter levels determined by the ratio of luciferase to $\beta$-galactosidase activity and expressed as 1 , and after transfection of either Pitx1 (+) or Hesx1 (+). The Pitx1 DNA binding sites are depicted by open boxes.

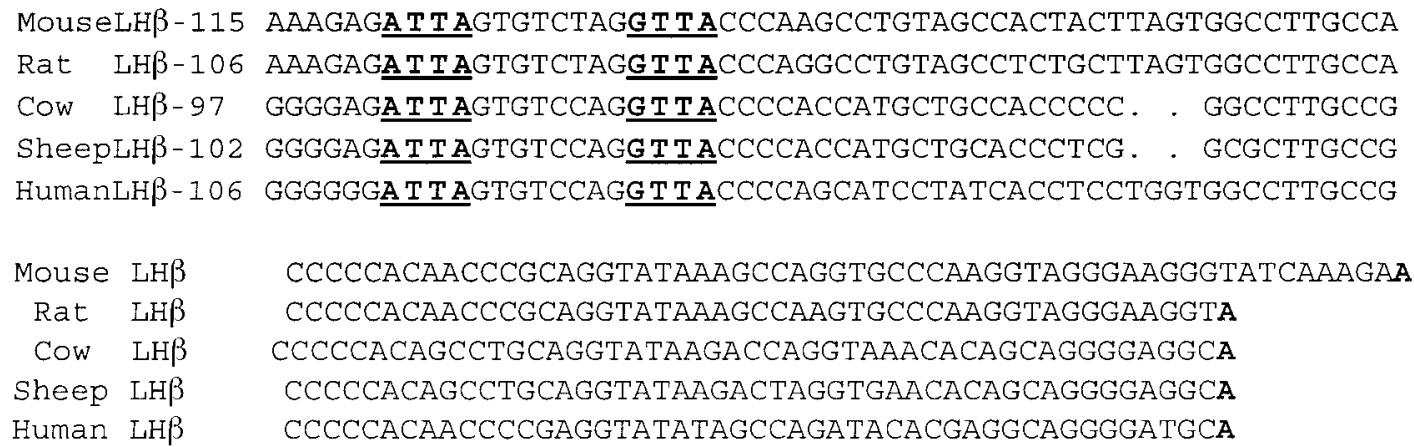

Figure 3 Conservation of a second potential homeodomain binding site in the LH $\beta$ promoter. LH $\beta$ promoter sequences from mouse, rat, cow, sheep and human were aligned using GCG version 10.2 (Genetics Computer Group). A 19 bp sequence containing a homeodomain consensus binding element (ATTA), and a second potential homeodomain binding site (GTTA) is highly conserved across species. Transcription start sites are shown (bold).

homeodomain binding site was used in a database sequence similarity search across the LH $\beta$ gene promoters of other species and the DNA sequence line-up is shown in Fig. 3. There was complete conservation of the sequence across these species.

\section{Hesx1 can antagonise Pitx1 transactivation}

To investigate the cognate DNA binding sites for Pitxl from the $\alpha \mathrm{GSU}$ and LH $\beta$ gene promoters, and the putative homeodomain DNA binding site identified in $\mathrm{LH} \beta$, a series of constructs were built. Three copies of the DNA sequence from $\alpha \mathrm{GSU}$ $\left(5^{\prime}\right.$-agCTTAtgtgcctgatccetg- $\left.3^{\prime}\right)$ or LH $\beta \quad\left(5^{\prime}-\right.$ agATTAgtgtccagGTTAc- $3^{\prime}$ ), or a PIII consensus site $\left(5^{\prime}\right.$-ttgagtc TAATtgaATTActgtacagc- $\left.{ }^{\prime}\right)$ known to bind Hesx 1 as a homodimer (Dattani et al. 1998), were fused upstream of a minimal thymidine kinase promoter. Transfection of each of these DNA 

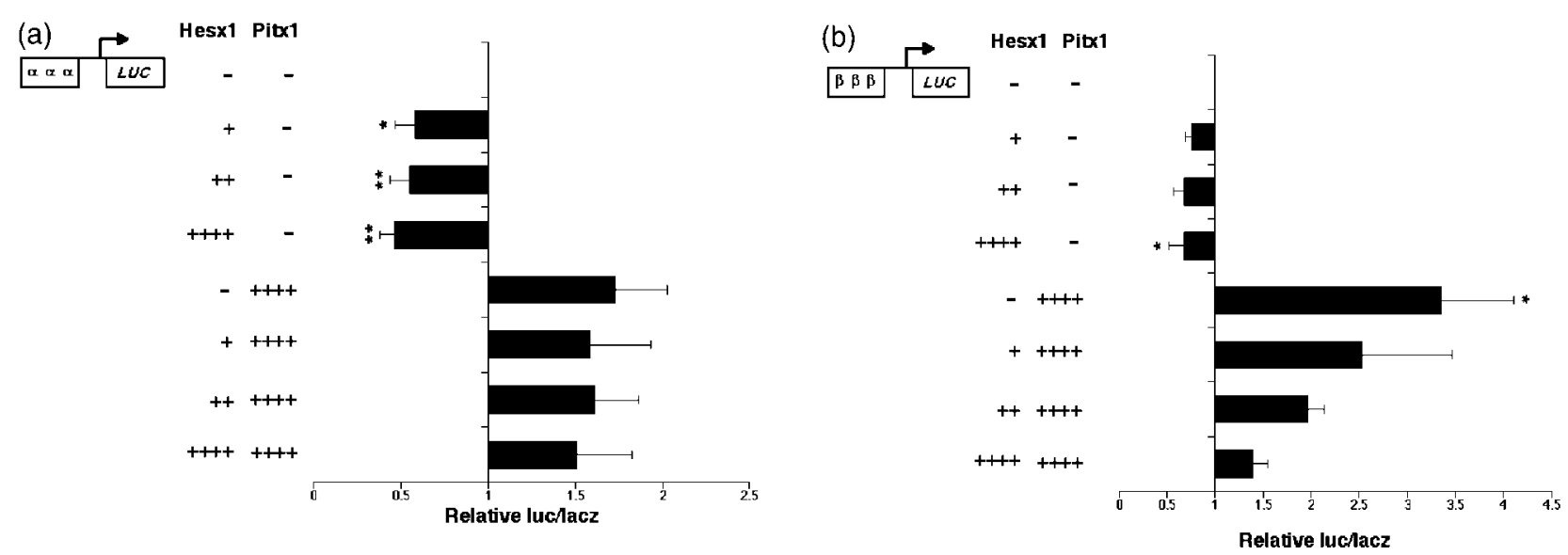

Figure 4 Hesx1 can antagonize Pitx1 transactivation of the LH $\beta$ Pitx1 DNA binding site, but not $\alpha$ GSU. DNA constructs containing three copies of the Pitx1 DNA binding site from $\alpha \mathrm{GSU}, \mathrm{LH} \beta$ and a consensus paired DNA binding site (PIII) were transfected into HeLa cells with varying amounts of Hesx1 or Pitx1 or both. (a) Hesx1 repressed the $\alpha \mathrm{GSU}$ trimer. Pitx 1 increased luciferase activity, and this was not affected by

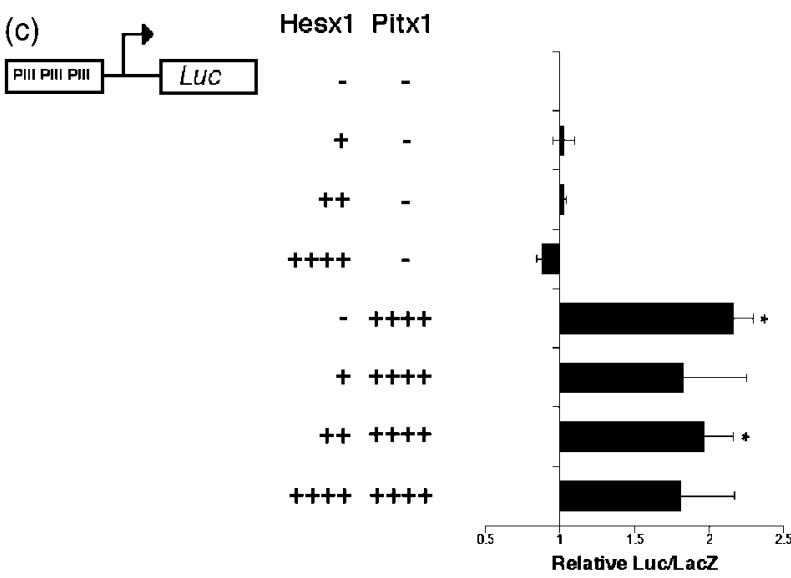
co-transfection of Hesx1. ${ }^{* \star} P<0.01, \alpha$ GSU trimer vs $\alpha \mathrm{GSU}$ trimer and ++ or ++++ Hesx1; ${ }^{*} P<0.05, \alpha \mathrm{GSU}$ trimer vs $\alpha$ GSU trimer and + Hesx1. (b) Hesx1 marginally repressed the $\mathrm{LH} \beta$ trimer. Luciferase activity was increased by co-transfection of Pitx1, and activity decreased in a dose-dependent manner when Hesx1 was co-transfected. ${ }^{*} P<0.05$, $\mathrm{LH} \beta$ trimer vs $\mathrm{LH} \beta$ trimer and ++++ Hesx 1 and LH $\beta$ trimer and ++++ Pitx1. (c) PIII was insensitive to Hesx1. Pitx1 transactivated the PIII trimer, and this was not affected by co-transfection of Hesx1. ${ }^{*} P<0.05$, PIII trimer vs PIII trimer and ++++ Pitx1 or ++++ Pitx1 and ++ Hesx1. Relative activity was standardised to basal promoter activity, expressed as 1, and was calculated as the ratio of luciferase to a control $\beta$-galactosidase construct. Hesx1 and Pitx1 were either omitted $(-)$ or transfected in amounts of $125 \mathrm{ng}(++++)$, $63 \mathrm{ng}(++)$ or $31 \mathrm{ng}(+)$.

constructs with Pitxl increased reporter gene expression, including PIII (Fig. 4a, b and c). However, Hesx 1 repression of expression appeared to be graded in the three constructs. Hesxl strongly repressed basal gene expression of the Pitxl DNA binding site from the $\alpha$ GSU promoter (Fig. 4a); in contrast there was little to moderate repression of the LH $\beta$ trimer, and repression increased with increasing amounts of Hesxl (Fig. 4b). There was minimal to no repression of PIII when Hesx l was co-transfected (Fig. 4c). In agreement with the promoter resection data, Hesxl did not repress or antagonise Pitxl transactivation of the aGSU

trimer (Fig. 4a). There was variation in the amount of Pitxl mediated transactivation when Hesxl was co-transfected, possibly implying weak interference of Hesx 1 for the same DNA binding site, or simply variation in the levels of Pitxl stimulation. However, Pitxl transactivation of the LH $\beta$ paired DNA binding site was clearly antagonised by Hesxl in a dose-dependent manner (Fig. 4b). Indeed, when Pitx 1 and Hesx 1 were transfected in equivalent amounts, Hesx 1 nearly abolished Pitx 1 transactivation via the LH $\beta$ homeodomain DNA binding site. Interestingly, Hesxl did not antagonise Pitxl transactivation of the PIII construct (Fig. 


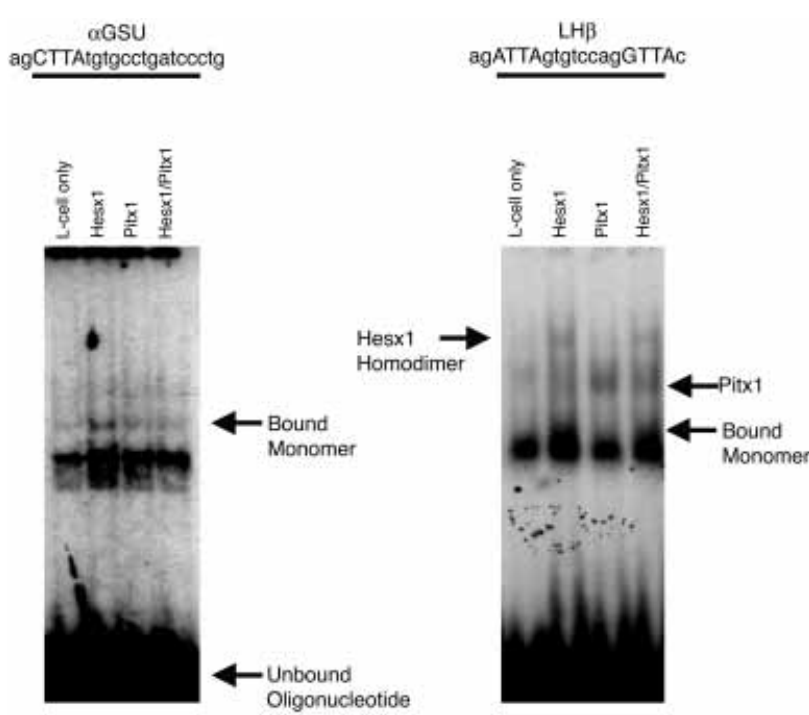

Figure 5 Hesx 1 protein binds to $\alpha$ GSU and LH $\beta$ homeodomain DNA elements. Nuclear extracts from untransfected L-cells, or from L-cells transfected with Hesx1 or Pitx1 were used in EMSA analysis of homeodomain binding sites in $\alpha \mathrm{GSU}$ and LH $\beta$. Specific bound complexes and free probe are indicated. Hesx1 bound $\alpha \mathrm{GSU}$ as a monomer, and $\mathrm{LH} \beta$ as a homodimer. Pitx 1 competed off Hesx 1 bound to $\alpha$ GSU. Presence of Pitx1 did not interfere with Hesx1 homodimer formation on $\mathrm{LH} \beta$ and no Hesx1/Pitx1 heterodimer was observed on LH $\beta$. A 4\% PAGE gel was used to resolve complexes bound by $\mathrm{LH} \beta$.

4c), even though Hesxl has been shown to homodimerise on this DNA element (Dattani et al. 1998).

\section{EMSA analysis of a novel paired DNA binding site from LH $\beta$}

Hesx 1 differentially represses the $\alpha \mathrm{GSU}$ and $\mathrm{LH} \beta$ gene promoters via the Pitxl DNA binding site. Furthermore, Hesxl can only antagonise Pitxl on the paired binding site contained within the LH $\beta$ promoter. Therefore, EMSA was used to analyse potential binding of Hesx 1 protein to $\alpha \mathrm{GSU}$ and LH $\beta$ dsoligonucleotides. Hesx 1 protein was isolated as part of a mouse L-cell nuclear extract and incubated with $\alpha \mathrm{GSU}$ and LH $\beta$ DNA elements (Fig. 5). Specific Hesxl shifted complexes were observed for each oligonucleotide, that were distinct from endogenous L-cell complexes. The specific Hesxl complex, shifted by the $\alpha \mathrm{GSU}$ dsoligonucleotide, was smaller than that of LH $\beta$. The binding of Hesxl to the $\alpha \mathrm{GSU}$ and LH $\beta$ elements was also compared and contrasted to binding in the absence and presence of nuclear extract containing Pitxl (Fig. 5). Although Pitx1 binding to the $\alpha \mathrm{GSU}$ dsoligonucleotide was weak, there was clearly a shifted Pitxl complex on the LH $\beta$ dsoligonucleotide. There was no evidence of a larger Hesx 1 complex forming on the $\alpha \mathrm{GSU}$ dsoligonucleotide, confirming that a Hesx 1 homodimer did not form on this site, and this monomeric Hesxl shifted complex was competed when Pitxl-containing extract was added, as evidenced by the decrease in Hesxl complex formation. In contrast, the Hesxl specific homodimer complex shifted by LH $\beta$ persisted when nuclear extract containing Pitxl was added. Furthermore, although there was some weak residual Pitxl binding to $\mathrm{LH} \beta$, there was no evidence of a Hesx 1 and Pitxl protein heterodimer forming on this element, even on prolonged exposure of the gel.

The homodimerisation of Hesxl on the LH $\beta$ dsoligonucleotide was studied using a series of oligonucleotides with mutations in one or both sites. Either the Pitxl site or the second site was mutated, and compared with binding of Hesx 1 to $\alpha \mathrm{GSU}$ (Fig. 6). EMSA experiments were undertaken with these oligonucleotides using either L-cell nuclear extracts or L-cell nuclear extracts containing Hesxl (Fig. 6). Hesxl bound the wild-type sequence as a homodimer, mutation of the 5'-ATTA-3' DNA binding site abolished complex formation, with weak monomer binding (Fig. 6, M1). Mutation of $5^{\prime}$-ATTA-3' to the Pitxl DNA binding site in the aGSU promoter 5'-CTTA-3' also prevented homodimer complex formation (Fig. 6, M2); however, again a weak monomer complex was formed. In contrast, mutation of 5'-GTTA-3' to 5'-GGTA-3' (Fig. 6, M3) markedly reduced both homodimer and monomer complex formation, when compared with wild-type. Although prolonged exposure of the gel indicated that some homodimer did form, the complex was very diffuse and weak (data not shown). Mutation of both sites completely abrogated homodimer and monomer complex formation (Fig. 6, M4). As a comparison, there was clear formation of a monomer on the aGSU dsoligonucleotide (Fig. 6, aGSU). These results suggest that Hesx 1 must bind both sites to form a homodimer, but that $5^{\prime}$-ATTA-3' is obligate, followed by co-operative binding to 5'-GTTA-3'. Furthermore, the lack of homodimerisation, but some monomer binding to 


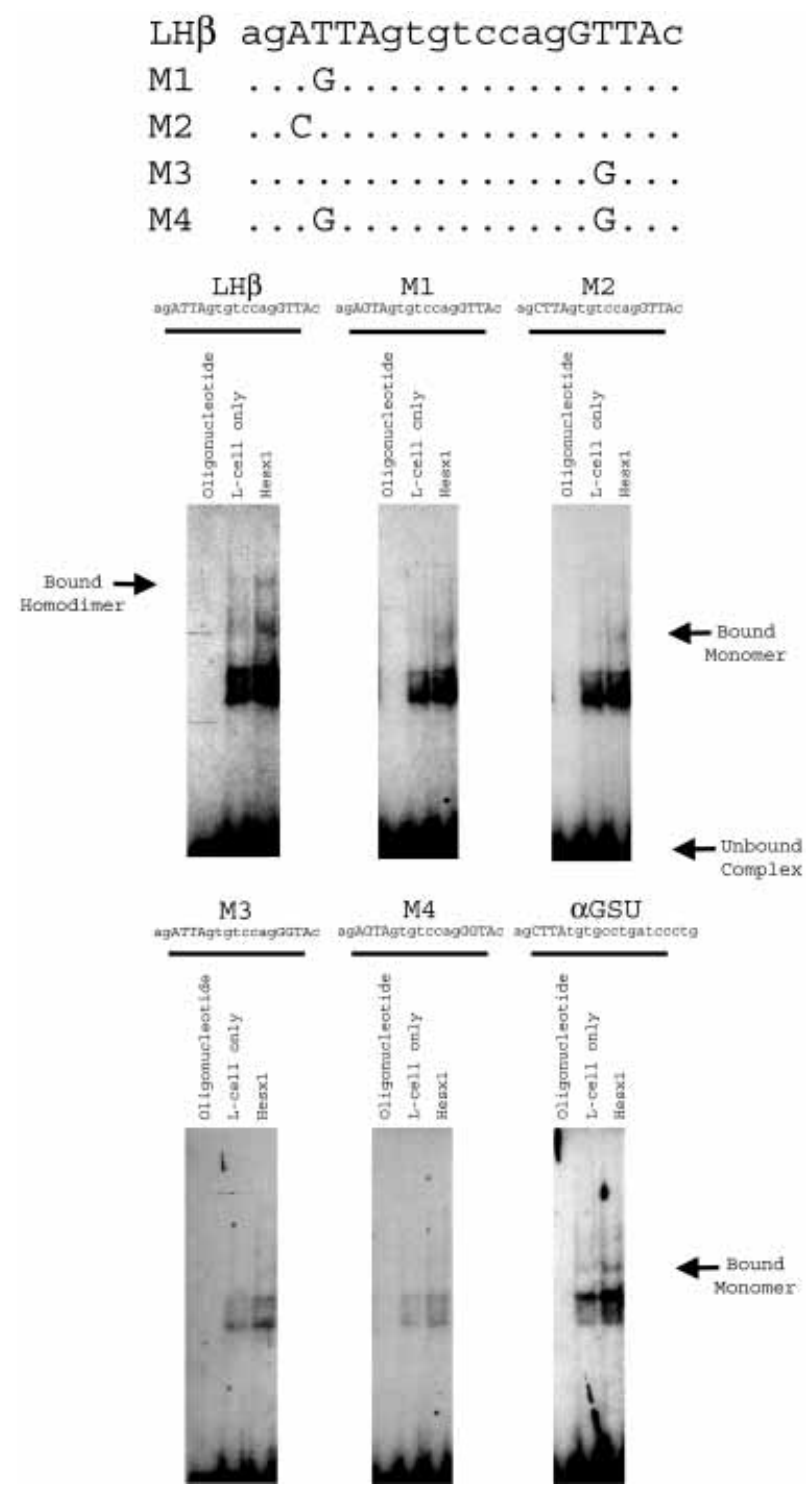

Figure 6 Mutational analysis of the LH $\beta$ homeodomain DNA binding site. Hesx 1 homodimerisation on $\mathrm{LH} \beta$ was investigated using dsoligonucleotides containing mutations in the homeodomain binding sites and nuclear extracts from untransfected L-cells or L-cells transfected with Hesx1. Free probe and specific bound monomer or homodimer complexes are indicated. The oligonucleotide sequences are shown above the autoradiograms. Hesx 1 binds wild-type $\alpha \mathrm{GSU}$ and LH $\beta$ oligonucleotides as a monomer and homodimer respectively. Mutation of either half of the LH $\beta$ homeodomain binding site reduced homodimer complex formation (M1, M2, M3 and M4). Hesx1 bound M1, M2, and $\alpha \mathrm{GSU}$ as a monomer.

oligonucleotide $\mathrm{M}$ 2, indicates that there is a hierarchy of Hesxl binding sites with monomer formation favouring 5'-CTTA-3'.

\section{Transfection analysis of a novel paired DNA binding site from $\mathrm{LH} \beta$}

Therefore, Hesx 1 antagonises Pitxl transactivation of the novel paired homeodomain DNA binding site in the LH $\beta$ promoter by homodimerising. If this paired homeodomain binding site is mutated, then Hesxl will no longer homodimerise. Three copies of the M3 oligonucleotide (5'agATTAgtgtccagGGTAc- $3^{\prime}$ ) were ligated upstream of a minimal thymidine kinase promoter as already described. This was co-transfected with Hesxl, Pitxl or both and luciferase activity was assayed (Fig. 7). Substituting one base-pair markedly altered the luciferase expression of the construct, in response to co-transfection of either Hesxl or Pitxl or both. Hesxl only repressed activity when transfected at high concentrations and this may be a feature of occupancy of the 5'-ATTA-3' site, since lower concentrations resulted in a weak transactivation. Pitxl still transactivated the construct, although weakly when compared with wild-type, and when Hesx 1 and Pitxl were co-transfected there was no dosedependent antagonism of Pitxl transactivation.

\section{Discussion}

We have analysed Hesxl modulation of gene expression in vitro, in an effort to understand how this transcriptional repressor operates. To study this, we used the gonadotrophin gene promoters, and found that both $\alpha \mathrm{GSU}$ and LH $\beta$ gene promoters were repressed by Hesxl. Resections mapped this repression to the paired-like Pitxl DNA binding site contained within $-120 \mathrm{bp}$ of $\alpha \mathrm{GSU}$, but outside the Pitxl DNA binding site contained within the LH $\beta$ gene promoter. Since the DNA sequence of these Pitxl binding sites only differs by one base-pair, this difference in repression of gene expression was further investigated and compared with Pitxl transactivation of the same promoters. In this instance, Hesxl did not repress Pitxl transactivation of $-120 \mathrm{bp} \alpha \mathrm{GSU}$, but did modulate Pitxl transactivation of $-136 \mathrm{bp}$ LH $\beta$ promoter. This difference was due to the presence of a novel paired DNA binding site 5'agATTAgtgtccagGTTAc-3' contained within the -136 bp LH $\beta$ promoter, that is conserved across species. Indeed, when these DNA binding sites were cloned upstream of a minimal promoter, 


\section{Hesx1 Pitx1}
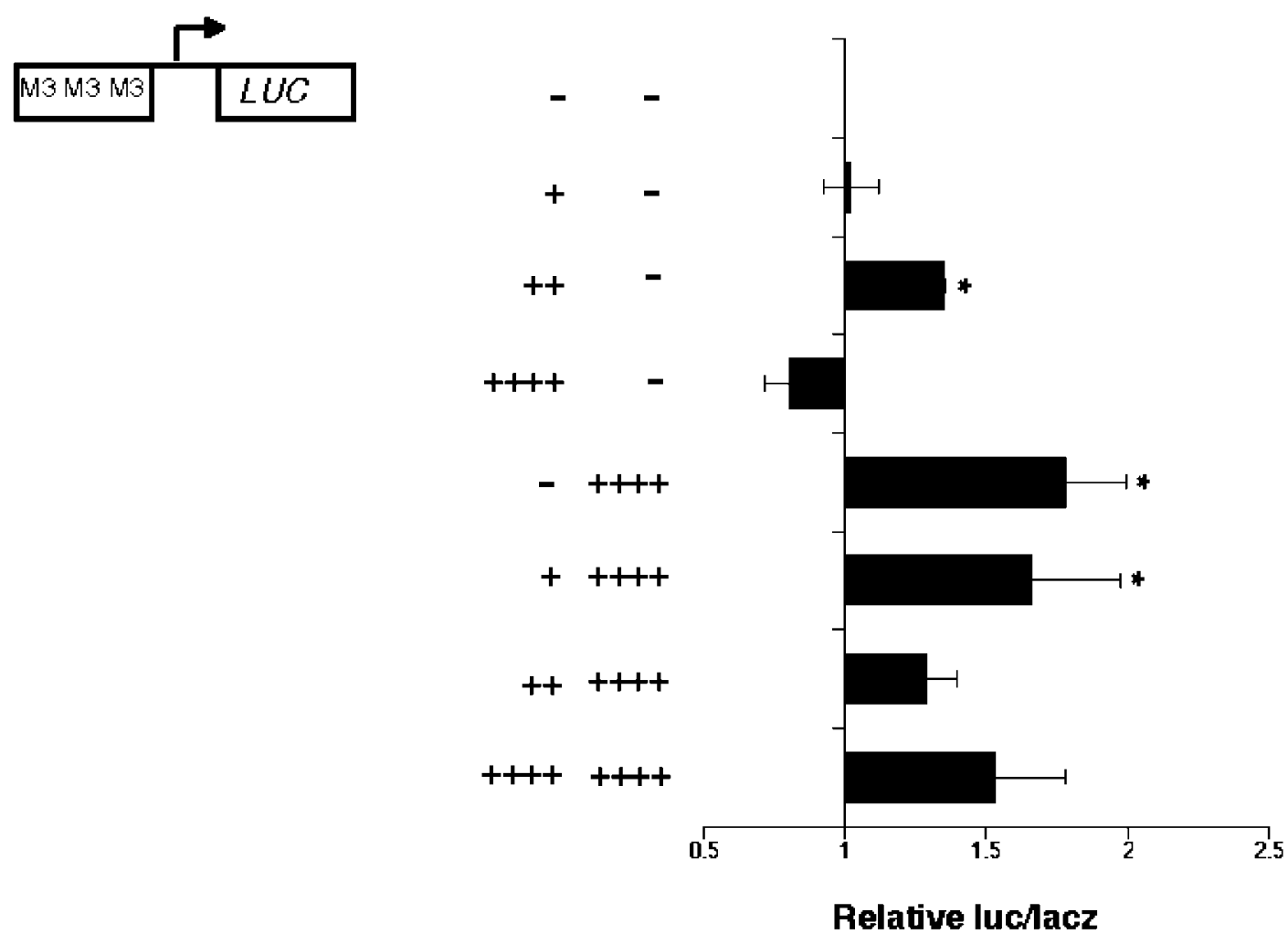

Figure 7 Hesx 1 homodimer formation and subsequent antagonism of Pitx1 transactivation requires an intact 5'-GTTA-3'. Trimeric DNA constructs of the mutant M3 oligonucleotide were transfected into HeLa cells with increasing amounts of Hesx1 or a constant amount of Pitx1 and increasing amounts of Hesx1. Hesx1 only repressed the M3 trimer at high concentrations. Pitx1 transactivated expression from the M3 trimer, but this was insensitive to co-transfection of increasing amounts of Hesx1. Relative activity was standardized to basal promoter activity, and was calculated as the ratio of luciferase to a control $\beta$-galactosidase construct. Hesx1 and Pitx1 were either omitted (-) or transfected in amounts of $125 \mathrm{ng}(++++), 63 \mathrm{ng}(++)$ or $31 \mathrm{ng}(+) .{ }^{*} P<0 \cdot 05$, M3 trimer vs M3 trimer and ++ Hesx1 or ++++ Pitx1 or ++++ Pitx1 and + Hesx1.

Hesx 1 strongly repressed basal $\alpha$ GSU activity, but minimally repressed $\mathrm{LH} \beta$, and had no effect on a PIII paired DNA binding site. EMSA analysis confirmed that Hesxl binds as a monomer to the Pitxl DNA binding site in aGSU (5'agCTTAtgtgcctgatccetg- $\left.3^{\prime}\right)$, but binds as a homodimer to the novel paired DNA binding site in LH $\beta$, described above. Furthermore, this homodimer persists, even in the presence of Pitxl DNA binding. Mutational analysis of the paired DNA site indicated that Hesx 1 preferentially bound the 5'-ATTA-3' DNA sequence, and once tethered at this site, cooperatively bound the 5'-GTTA-3' sequence forming a homodimer. This was further supported by mutation of the 5'-GTTA-3' site.
When this unique site was mutated and the construct subsequently tested for antagonism, Hesx 1 could no longer transcriptionally antagonise Pitxl.

Wild-type and chimaeric Hesxl proteins can act as transcriptional repressors in vivo (Ermakova et al. 1999) and in vitro by recruitment of the nuclear co-repressor N-CoR (Xu et al. 1998). This investigation expands these observations to include the $\alpha \mathrm{GSU}$ and LH $\beta$ gene promoters, and identifies specific DNA targets within them. Hesx l repression was mediated over the entire length of $-480 \mathrm{bp}$ $\alpha \mathrm{GSU}$ and -320 bp LH $\beta$ DNA promoters so, once bound, Hesxl interfered with the basal transcriptional apparatus. This indicates that Hesxl can act 


$$
\begin{aligned}
& \alpha G S U-480 \mathrm{bp} \\
& \text { AAATCCAGATGCCTGTTAATTAAGAAATTGGAGCAATTGTTTTATTTTTCTGTTTCCTGTTGAAATAATG } \\
& \text { TAATCCTGAAAATGTTTTTTTTATCCTGCTTTATGAAAATATCAGGTACTTAGCTAATTAAATGTGCTAC } \\
& \text { TCTTAGAGTCCIGTTTATTTTAAAAGTGTCAACTTTCAGGATGTTTTGTGTAAGGGTCAATAATATTACAT } \\
& \text { AGAAAATGGCCAAATGCTCTCTCTTCA TAAGCTGTCCTTGAGGTCACCACTACCTCAAAATGTCTAAAAAC } \\
& \text { AAAACTGATCTGAGGGTTGCAATGTGATATGATCAATTGATGTCATGGTAATTATACCAAGTGCCATCCAA } \\
& \text { TCACTGGGTAGAATTTACCCCTGATCCCTGAGCTTATGTGCAGCTGGGAACATGCAATTTGTATTACTCTG } \\
& \text { CTGGTATAAAAGACAGTGGGAGACT TTATTAACTGCAGGCACTGAAAAATCCAGA }
\end{aligned}
$$$$
\operatorname{LH} \beta-320 \mathrm{bp}
$$

Figure $8 \alpha G S U$ and LH $\beta$ gene promoters contain putative paired homeodomain DNA binding sites. Putative half-sites are shown in bold and those matching the Hesx1 binding sites identified in this study are underlined. Actual Hesx1 binding sites are highlighted (solid stars) and TATAA sequences are boxed.

as a short-range transcriptional repressor, since repression was mapped to within -120 bp on $\alpha \mathrm{GSU}$ and between -320 and -136 bp on the LH $\beta$ promoter. Short- and long-range repression of transcription is used to define the category of repressor: long-range repression is non-specific, controlling global locus silencing, while short-range repressors act at the promoter level and also specifically block transactivation (Courey \& Songtao 2001). There were no canonical paired DNA binding sites, defined by 5'-TAAT-3' palindromes separated by a $3 \mathrm{bp}$ spacer, in either promoter (Fig. 8); instead, each distal promoter fragment contained numerous copies of possible half-binding sites. Consistent with this, the half-site contained within the -120 bp $\alpha$ GSU promoter was bound as a monomer and expression from this promoter was strongly repressed by Hesxl. In addition, repression was mapped upstream of $-136 \mathrm{bp}$ in LH $\beta$, so again Hesxl repressed presumably via half-sites.
Hesx 1 only antagonised Pitxl transactivation of LH $\beta$ and not $\alpha$ GSU gene promoters. The lack of Hesxl antagonisation of Pitx l activated $\alpha \mathrm{GSU}$ gene expression was initially surprising, until the hitherto equivalent Pitxl binding sites in the promoters were actually found to be different. The Hesx 1 DNA binding site in the LH $\beta$ promoter was comprised of an imperfect inverted palindrome separated by an elongated 8 bp spacer. This DNA sequence was entirely novel, conserved across species and, importantly, was not repressed by Hesx1. There is known to be a high degree of redundancy in DNA binding site selection by homeodomain proteins, that is mediated by their context (Catron et al. 1993), and by the spacing of the core binding site (Tucker \& Wisdom 1999). However, conversion of the paired site in the LH $\beta$ promoter to the site present in the $\alpha \mathrm{GSU}$ promoter did not promote Hesxl homodimerisation, and instead Hesx 1 bound as a monomer to this site. 
Pitxl regulates gene expression by interacting with non-homeodomain binding proteins (Tremblay et al. 1999, Poulin et al. 2000, Lamolet et al. 2001). Hesxl did not heterodimerise with Pitxl on the LH $\beta$ paired DNA binding site. Although Pitxl can compete with Hesxl for the Pitxl site on the LH $\beta$ promoter, since Pitxl does not appear to dimerise, homodimerisation of Hesx 1 stabilizes DNA binding and antagonises Pitxl. This was supported by co-transfection of Hesxl and Pitx1, where transfecting increasing amounts of Hesxl progressively decreased Pitxl transactivation. In contrast, the $\alpha \mathrm{GSU}$ trimer, PIII trimer and M3 trimer were not antagonised by Hesxl, but there was variability in Pitxl transactivation. In these instances our data indicate that Hesxl is competing with Pitxl for monomeric DNA binding sites, but in every case co-transfection of increasing amounts of Hesxl did not antagonise transactivation in a dosedependent manner. This suggests that Hesxl and Pitx 1 factors probably have differing affinities for monomer binding sites, and this was reflected by the absence of antagonisation of Pitx l transactivation. In addition, these results also imply that although the PIII trimer can bind Hesx 1 as a homodimer (Dattani et al. 1998), the spacing is crucial for antagonisation of Pitxl transactivation. The PIII trimer contains a $3 \mathrm{bp}$ linker, while the LH $\beta$ paired sites are separated by $8 \mathrm{bp}$. However, there may be an encrypted $\alpha \mathrm{GSU}$ like binding site for Pitxl contained within the PIII DNA element (5'-ttgagtcTAATtgaATTA ctgtacagc- $3^{\prime}$ ) that could also account for these differences.

Our observation that Hesx 1 can repress $\alpha \mathrm{GSU}$ gene expression in vitro could have significant consequences for expression during embryonic development. Studies from a number of groups indicate that the expression patterns of $\alpha \mathrm{GSU}$ and Hesx 1 overlap in the developing anterior pituitary, and that as Hesx 1 expression regresses in a ventral to dorsal manner, coincidently aGSU expression increases (Burrows et al. 1996, Hermesz et al. 1996). Pitxl and aGSU co-localise in embryonic cells (Lanctot et al. 1999), and Pitxl is required for efficient $\alpha \mathrm{GSU}$ gene expression (Tremblay et al. 1998, Szeto et al. 1999). Furthermore, Pitxl protein levels decline (Lanctot et al. 1999) coincident with restriction of Hesx l to Rathke's pouch (Hermesz et al. 1996), but significantly recover as Hesx 1 expression declines. However, there is no evidence that Hesx 1 can regulate pituitary expression of Pitxl or vice versa.

Pitx 1 is also required for $\mathrm{LH} \beta$ gene expression in mice (Quirk et al. 2001 and references therein), and affects lineage specification and maintenance of gonadotrophs (Szeto et al. 1999). There are numerous incidences of persistent expression of Hesx1 (Gage et al. 1996, Wu et al. 1998), and in these instances, gonadotroph terminal differentiation markers fail to express. Our observations of Hesxl repression and antagonism of Pitxl transactivation of LH $\beta$ gene expression could explain the delay in expression of gonadotroph terminal differentiation markers in Prop-1 defective mice and patients (Gage et al. 1996, Wu et al. 1998) and also support a role for Hesxl in perturbation of terminal differentiation markers. Furthermore, it has not been established how $\alpha \mathrm{GSU}$ gene expression is activated, while LH $\beta$ gene expression remains quiescent during pituitary development. It is likely that, although Hesxl can act as a short-range repressor of $\mathrm{LH} \beta$, another factor which is expressed over a longer developmental timeframe mediates long-range repression and gene silencing. Control of the LH $\beta$ gene locus is undoubtedly complex, since studies in transgenic mice with a distal LH $\beta$ promoter documented premature promoter activation during embryogenesis ( $\mathrm{P}$ Brown and A S McNeilly, personal communication), although there was normal targeting and regulation of expression in gonadotrophs in adults (Brown et al. 1993, McNeilly et al. 1996). Therefore, control elements needed to silence and target LH $\beta$ gene expression during embryogenesis are probably located at greater distances than that reported for $\alpha \mathrm{GSU}$ (Brinkmeier et al. 1998).

A role for Hesxl in suppression of expression of gonadotroph cell markers as a monomer, and specific antagonism of gene expression as a homodimer also indicates that Hesx 1 gene expression levels are critical. Haploinsufficiency in mice, and the occurrence of septo-optic dysplasia and GPHD in man are both linked to Hesx 1 expression levels and the ability of Hesxl to homodimerise (Dattani et al. 1998, Thomas et al. 2001). The homodimerisation of Hesxl on LH $\beta$ and the repression of $\alpha \mathrm{GSU}$, which was efficiently repressed by low concentrations of Hesx 1, imply that Hesxl could have a two-tier mode of action. 
Repression of target gene expression could be relatively insensitive to levels of Hesxl, since this only requires Hesxl to bind as a monomer, whereas antagonism either by homo- or heterodimerisation could be critically dependent on the levels of Hesx 1 gene expression. This model is also consistent with the proposed threshold response gradient action of the paired-like homeodomain factor, bicoid, in Drosophila (Burz et al. 1998).

In conclusion, our results show that Hesx 1 can suppress expression of both the $\alpha \mathrm{GSU}$ and LH $\beta$ gene promoters. Hesxl repression of $\alpha \mathrm{GSU}$ is overridden by Pitxl, and was mediated via the Pitxl DNA binding site contained within the proximal $\alpha \mathrm{GSU}$ promoter. In contrast, Hesx 1 repression of $\mathrm{LH} \beta$ mapped out with the equivalent proximal Pitxl DNA binding site. Instead, Hesx 1 antagonised Pitxl transactivation of the promoter in a dose-dependent manner, by binding as a homodimer to a novel DNA homeodomain binding site that encompassed the LH $\beta$ Pitxl transactivation site.

\section{Acknowledgements}

We thank Professor PJ Rathgen, Melbourne, Australia, for the Hesxl cDNA clone and David Gordon, Denver, Colorado, USA for the generous gift of the -480 , and $-120 \mathrm{bp} \alpha \mathrm{GSU}$ promoter constructs and the pA3 LUG vector. Additionally, we acknowledge the technical support of Gwen Crawford and thank Jason Maini for his technical contribution to this work. Manuscripts supporting the role of Hesxl in gonadotrophs were published following submission of this article (Brickman et al. 2001, Dasen et al. 2001).

\section{References}

Acampora D, Mazan S, Tuorto F, Avantaggiato V, Tremblay JJ, Lazzaro D, di Carlo A, Mariano A, Macchia PE, Corte G, Macchia V, Drouin J, Brulet P \& Simeone A 1998 Transient dwarfism and hypogonadism in mice lacking Otxl reveal prepubescent stage-specific control of pituitary levels of GH, FSH and LH. Development 125 1229-1239.

Bach I, Rhodes SJ, Pearse IRV, Heinzel T, Gloss B, Scully KM, Sawchenko PE \& Rosenfeld MG 1995 p-Lim, a LIM homeodomain factor, is expressed during pituitary organ and cell commitment and synergizes with Pit-1. PNAS 92 2720-2724.

Brickman JM, Clements M, Tyrell R, McNay D, Woods K, Warner J, Stewart A, Beddington RS \& Dattani M 2001 Molecular effects of novel mutations in Hesxl/HESX1 associated with human pituitary disorders. Development 128 5189-5199.

Brinkmeier ML, Gordon DF, Dowding JM, Saunders TL, Kendall SK, Sarapura VD, Wood WM, Ridgway EC \& Camper SA 1998 Cell-specific expression of the mouse glycoprotein hormone $\alpha$-subunit gene requires multiple interacting DNA elements in transgenic mice and cultured cells. Molecular Endocrinology 12 622-633.

Brown P \& McNeilly AS 1999 Transcriptional regulation of pituitary gonadotrophin subunit genes. Reviews of Reproduction 4 117-124.

Brown P, McNeilly JR, Wallace RM, McNeilly AS \& Clark AJ 1993 Characterization of the ovine $\mathrm{LH} \beta$-subunit gene: the promoter directs gonadotrope-specific expression in transgenic mice. Molecular and Cellular Endocrinology 93 157-165.

Burrows HL, Birkmeier TS, Seasholtz AF \& Camper SA 1996 Targeted ablation of cells in the pituitary primordia of transgenic mice. Molecular Endocrinology 10 1467-1477.

Burz DS, Rivera-Pomar R, Jackle H \& Hanes SD 1998 Cooperative DNA-binding by Bicoid provides a mechanism for thresholddependent gene activation in the Drosophila embryo. EMBO Fournal 17 5998-6009.

Catron KM, Iler N \& Abate C 1993 Nucleotides flanking a conserved TAAT core dictate the DNA binding specificity of three murine homeodomain proteins. Molecular and Cellular Biology $132354-2365$.

Courey AJ \& Songtao J 2001 Transcriptional repression: the long and the short of it. Genes and Development 15 2786-2796.

Cushman LJ, Watkins-Chow DE, Brinkmeier ML, Raetzman LT, Radak AL, Lloyd RV \& Camper SA 2001 Persistent Propl expression delays gonadotrope differentiation and enhances pituitary tumor susceptibility. Human Molecular Genetics 10 1141-1153.

Dasen JS \& Rosenfeld MG 1999 Combinatorial codes in signalling and synergy: lessons from pituitary development. Current Opinion in Genetics and Development 9 566-574.

Dasen JS, Barbera JP, Herman TS, Connell SO, Olson L, Ju B, Tollkuhn J, Baek SH, Rose DW \& Rosenfield MG 2001 Temporal regulation of a paired-like homeodomain repressor/TLE corepressor complex and a related activator is required for pituitary organogenesis. Genes \& Development 15 3193-3207.

Dattani MT, Martinez-Barbera JP, Thomas PQ Brickman JM, Gupta R, Martensson IL, Toresson H, Fox M, Wales JKH, Hindmarsh PC, Krauss S, Beddington RSP \& Robinson ICAF 1998 Mutations in the homeobox gene HESX1/Hesx l associated with septo-optic dysplasia in human and mouse. Nature Genetics 19 125-133.

Ermakova GV, Alexandrova EM, Kazanskaya OV, Vasiliev OL, Smith MW \& Zaraisky AG 1999 The homeobox gene, Xanf-1, can control both neural differentiation and patterning in the presumptive anterior neurectoderm of the Xenopus laevis embryo. Development 126 4513-4523.

Gage PJ, Brinkmeier ML, Scarlett LM, Knapp LT, Camper SA \& Mahon KA 1996 The Ames dwarf gene, df, is required early in pituitary ontogeny for the extinction of Rpx transcription and initiation of lineage-specific cell proliferation. Molecular Endocrinology 10 1570-1581.

Gage PJ, Suh H \& Camper SA 1999 Dosage requirement of Pitx2 for development of multiple organs. Development 126 4643-4651.

Hermesz E, Mackem S \& Mahon KA 1996 Rpx: a novel anteriorrestricted homeobox gene progressively activated in the prechordal plate, anterior neural plate and Rathke's pouch of the mouse embryo. Development 122 41-52.

Lamolet B, Pulichino AM, Lamonerie T, Gauthier Y, Brue T, Enjalbert A \& Drouin J 2001 A pituitary cell-restricted T box factor, Tpit, activates POMC transcription in cooperation with Pitx homeoproteins. Cell 104 849-859. 
Lamonerie T, Tremblay JJ, Lanctot C, Therrien M, Gauthier Y \& Drouin J 1996 Ptxl, a bicoid-related homeobox transcription factor involved in transcription of the pro-opiomelanocortin gene. Genes and Development 10 1284-1295.

Lanctot C, Gauthier Y \& Drouin J 1999 Pituitary homeobox 1 (Ptxl) is differentially expressed during pituitary development. Endocrinology 140 1416-1422.

McNeilly JR, Brown P, Mullins JJ, Clark AJ \& McNeilly AS 1996 Characterization of the ovine LH $\beta$-subunit gene: the promoter is regulated by $\mathrm{GnRH}$ and gonadal steroids in transgenic mice. Journal of Endocrinology 151 481-489.

Poulin G, Lebel M, Chamberland M, Paradis FW \& Drouin J 2000 Specific protein-protein interaction between basic helix-loop-helix transcription factors and homeoproteins of the Pitx family. Molecular and Cellular Biology 20 4826-4837.

Quirk CG, Lozada KL, Keri RA \& Nilson JH 2001 A single Pitx 1 binding site is essential for activity of the LH $\beta$ promoter in transgenic mice. Molecular Endocrinology 15 734-746.

Schreiber E, Matthias P, Muller MM \& Shaffner W 1989 Rapid detection of octomer binding proteins with 'mini-extracts' prepared from a small number of cells. Nucleic Acid Research 176419.

Sheng HZ, Zhadanov AB, Mosinger JB, Fujii T, Bertuzzi S, Grinberg A, Lee EJ, Huang SP, Mahon KA \& Westphal H 1996 Specification of pituitary cell lineages by the LIM homeodomain gene Lhx3. Science 272 1004-1007.

Sornson MW, Wu W, Dasen JS, Flynn SE, Norman DJ, O'Connell SM, Gukovsky L, Carriere C, Ryan AK, Miller AP, Zuo L, Gleiberman AS, Andersen B, Beamer WG \& Rosenfeld MG 1996 Pituitary lineage determination by the Prophet of Pit-1 homeodomain factor defective in Ames dwarfism. Nature $\mathbf{3 8 4}$ 327-333.

Szeto DP, Rodriguez-Esteban C, Ryan AK, O'Connell SM, Liu F, Kioussi C, Gleiberman AS, Izpisua-Belmonte JC \& Rosenfeld MG 1999 Role of the bicoid-related homeodomain factor Pitxl in specifying hindlimb morphogenesis and pituitary development. Genes and Development 13484494.

Thomas PQ, Dattani MT, Brickman JM, McNay D, Warne G, Zacharin M, Caneron F, Hurst J, Woods K, Dunger D, Stanhope
R, Forrest S, Robinson ICAF \& Beddington RSP 2001 Heterozygous HESX1 mutations associated with isolated congenital pituitary hypoplasia and septo-optic dysplasia. Human Molecular Genetics 10 39-45.

Treier M, Gleiberman AS, O’Connell SM, Szeto DP, McMahon JA, McMahon AP \& Rosenfeld MG 1998 Multistep signaling requirements for pituitary organogenesis in vivo. Genes and Development 12 1691-1704.

Tremblay JJ, Lanctot C \& Drouin J 1998 The pan-pituitary activator of transcription, Ptxl (pituitary homeobox 1), acts in synergy with SF-1 and Pitl and is an upstream regulator of the lim-homeodomain gene Lim3/Lhx3. Molecular Endocrinology 12 428-441.

Tremblay JJ, Marcil A, Gauthier Y \& Drouin J 1999 Ptxl regulates SF-1 activity by an interaction that mimics the role of the ligand-binding domain. EMBO fournal 18 3431-3441.

Tucker SC \& Wisdom R 1999 Site-specific heterodimerization by paired class homeodomain proteins mediates selective transcriptional responses. Fournal of Biological Chemistry 274 32325-32332.

Watkins-Chow DE \& Camper SA 1998 How many homeobox genes does it take to make a pituitary gland? Trends in Genetics $\mathbf{1 4}$ 284-290.

Wu W, Cogan JD, Pfaffle RW, Dasen JS, Frisch H, O'Connell SM, Flynn SE, Brown MR, Mullis PE, Parks JS, Phillips JA \& Rosenfeld MG 1998 Mutations in PROP1 cause familial combined pituitary hormone deficiency. Nature Genetics $\mathbf{1 8}$ 147-149.

Xu L, Lavinsky RM, Dasen JS, Flynn SE, McInerney EM, Mullen TM, Heinzel T, Szeto D, Korzus E, Kurokawa R, Aggarwal AK, Rose DW, Glass CK \& Rosenfeld MG 1998 Signal-specific co-activator domain requirements for Pit-1 activation. Nature 395 301-306.

Received 27 November 2001

Accepted 15 February 2002 